\title{
Tunteita ja tuoksuja: Aikuiskasvatuksen tutkijatapaaminen Jyväskylässä
}

\author{
Aikuiskasvatuksen tutkijatapaamiseen mahtui iloisia \\ kohtaamisia, kriittistä keskustelua, ajankohtaista \\ tutkimustietoa ja käytännön innovaatioita. \\ Erityisesti tapahtuma toi tunteet aikuiskasvatuksen \\ tutkimuskentälle - kenties ihan jäädäkseen.
}

AVOIN, VALOISA AULA, innostusta, jännittyneitä leukaperiä ja yli 200 kiiltäväpintaista nimikylttiä. Niillä aloitettiin Aikuiskasvatuksen tutkijatapaaminen Jyväskylän yliopiston Ruusupuistossa. Tapahtuman teema, Oppiminen, luovuus ja tunteet aikuisuuden eri elämänkentillä, liittyi kiinteästi Jyväskylän yliopiston kasvatustieteiden tiedekunnan opetuksen ja tutkimuksen vahvuusalueisiin.

Oppiminen, luovuus ja tunteet pilkahtelivat esiin pitkin tapahtumaa. Tilaisuuden luotsasi alkuun Ruusupuiston oma Rupuset-kuoro, joka tunnelmoi Semmareiden tahtiin: "Mahtava meininki hississä feel, feel, feel your body".

Oman jännityksensä tapahtumaan toi Ruusupuisto-rakennuksen testaaminen konferenssikäytössä. Tutkijatapaaminen oli ensimmäinen iso kon- ferenssitapahtuma uutuuttaan huokuvassa talossa. Ruusupuistoa kokeiltiin rakennuksena aivan uudella tavalla, kun talon avoimuuden ja yhteisöllisyyden hengessä pääluentoja ja paneelikeskustelua saattoi seurata reaaliaikaisesti eri puolilla rakennusta. Teemaryhmät kokoontuivat myös aulatiloissa.

Iltatilaisuudessa vierailla oli mahdollisuus muun muassa osallistua sosiaaliseen sirkukseen. Mahtavaa heittäytymistä nähtiinkin kollektiivisen jonglöörauksen ja hulvattomien supersankareiden rakentelun merkeissä.

\section{OPPIMINEN AIKUISTEN ELÄMÄNKENTILLÄ}

Ensimmäisen päluennon piti professori Päivi Tynjälä Jyväskylän yliopiston koulutuksen tutkimuslaitok- 
selta. Tynjälän tutkimusalueena ovat opetus ja oppiminen korkeakoulutuksessa ja työssä oppiminen. Tynjälä esitteli Oppiminen aikuisten elämänkentillä -luennossaan katsauksen ajankohtaisiin tutkimuksiin oppimisen, työssä oppimisen, toimijuuden ja emootioiden aloilta.

Viime aikoina varsinkin työssä oppiminen on ollut tärkeä ja laaja tutkimusala, johon on yhdistynyt vähitellen ja kasvavassa määrin myös toimijuuden ja emootion käsitteet. Ihminen kun ymmärretään kokonaisuutena, joka vaikuttuu ja vaikuttaa kokonaisvaltaisesti.

Tynjälä muistutti, että paljon tutkittuna aiheena aikuisten oppimiseen liitetään helposti uusia käsitteitä, jotka kuitenkin pyörivät saman asian ympärillä. Hän peräänkuulutti uusien pedagogisten jäsennysten ja toimintatapojen rakentamista, jotka ottavat huomioon sen, että oppimista tapahtuu kaikessa ja kaiken aikaa.

Tynjälä toi esiin, että asiantuntijatoiminta on inhimillistä toimintaa. Asiantuntija on toimijana sosiaalinen, kognitiivinen ja emotionaalinen olento, jonka toimintaan vaikuttavat monet tekijät. Asiantuntijan ei tarvitse olla tietystä muotista valettu. Oppimisen kannalta olennaista on kyetä välillä reflektoimaan sitä, miksi toimii tietyllä tavalla ja millaisia vaikutuksia sillä on ympäristöön. Näin asiantuntija voi kehittyä ja kehittää niin itseään kuin työympäristöään.

Selvää on, että aikuisten oppimisella on iso merkitys, kun halutaan vastata maailmanlaajuisiin ongelmiin. Tynjälän mukaan tarvitaan kollektiivista, eettistä ja arvotietoista oppimista pikemmin kuin nimellistä ja arvovapaata yksilön oppimista, jotta kyetään luomaan uusia, innovatiivisia ratkaisuja nyt ja tulevaisuudessa.

Tynjälän luento sai innostuneen vastaanoton, kuulijat olivat erityisesti kiinnostuneita kuulemaan lisää tunteiden tutkimisesta oppimisessa niin korkeakoulutuksessa kuin työelämässä.

\section{TUNTEET (TYÖ)ELÄMÄSSÄ}

Toisen pääluennon, Tunteet (työ)elämässä, piti psykologi, kirjailija, työyhteisövalmentaja ja omien sanojensa mukaan tunteiden ja persoonallisuuspsykologian ikuinen ihmettelijä ja elinikäinen opiskelija Jarkko Rantanen (PsM, Academy of Emotions).
Rantasen mielenkiintoinen, rehellinen ja inspiroiva luento oli oivallinen avaus toisena tapahtumapäivänä. Jöröjen kuulijoiden mielenkiinto heräsi viimeistään siinä vaiheessa, kun Rantanen lupasi, että tunteista ei ole pakko puhua. Ai ei ole vai? Mitä järkeä "tunnehössötyksessä" sitten on?

Rantanen opasti, että tunteiden johtaminen vaikuttaa merkityksellisesti menestymiseen työssä ja organisaatioissa. Tunteet ovat läsnä jokaisessa työn tekemisen hetkessä. Selväksi kävi, että tunteiden johtaminen on tärkeää. Valitettavasti tietämisen ja toimimisen välillä on ainakin toistaiseksi syvä kuilu. Tiedetään, että tunteet ovat tärkeitä ja monesti kuulee sanottavan, että työpaikoille haetaan hyvää fiilistä, mutta käytännössä tunteita ei oteta huomioon.

Rantanen selvitti, että menestyksekäs tunteiden johtaminen ei ole pelleilyä. Tunteiden johtaminen ei tarkoita välttämättä yksilöllisistä tunteista puhumista, vaan toimimista tavoilla, joissa tunteet otetaan huomioon. Tunteet ovat tietoa ja energiaa, jotka antavat voimaa tekemiseen. Toisaalta ne voivat lamaannuttaa.

Organisaation menestymisen kannalta olennaista on tiedostaa tunteiden olemassaolo ja luoda ilmapiiri, joka sallii erilaiset tunteet ja niistä tarvittaessa puhumisen ja oivaltaa, että tunteisiin vaikuttamisen kautta voi vaikuttaa työn tekemiseen. Tunteiden kärki työpaikoilla koostuu uteliaisuuden herättämisestä, hämmennyksen ja hämmästyksen arvostamisesta sekä kiitollisuuden korostamisesta.

Rantanen kehotti huomaamaan, että tunteet viestivät. Jokainen meistä rakentaa tunneilmapiiriä työpaikalla. Ilmeet, eleet, jopa kävelytyylin rytmi viestivät, millä tuulella olemme. Omien tunteiden ymmärtäminen ja johtaminen ovat tärkeitä, jotta voidaan oppia kohtaamaan muidenkin tunteita ja rakentamaan työpaikan tunneilmapiiriä. Meistä kaikista on - ainakin henkilökohtaisiksi - tunneasiantuntijoiksi.

\section{LUOVUUDEN, INNOVATIIVISUUDEN JA TUNTEIDEN JOHTAMINEN}

Rantasen luennon päätyttyä hypättiin Ruusupuiston olohuoneeseen. Siellä oli vuorossa paneelikeskustelu opettajankoulutuslaitoksen johtajiston eli Emma Kostiaisen, Matti Rautiaisen, Tiina Silande- 
rin ja Mirja Tarnaisen johdolla. Paneelikeskustelun aiheena oli luovuuden, innovatiivisuuden ja tunteiden johtaminen työorganisaatioissa. Paneelin asiantuntijoina toimivat Jarkko Rantanen, valmentaja ja kouluttaja Hilkka Alatalo-Korpi (HAK Leadership \& Coaching), FT ja kasvuyrityksen kehittäjä Outi Ihanainen-Rokio (Growthsetters, Duunitalli Oy) ja kirurgian professori Jukka-Pekka Mecklin (KeskiSuomen Sairaanhoitopiiri).

Tunteista puhuminen työpaikoilla etenkin asiantuntijatyössä, tuntuu olevan jonkinlainen tabu. Tunteista puhujat leimataan helposti "hörhöiksi", jotka eivät keskity olennaiseen. Kun tunteista puhutaan, ne usein tieteellistetään. Paneelikeskustelussa olikin tarkoitus kokoontua rennosti Ruusupuiston olohuoneeseen jakamaan aitoja tunnelmia ja kokemuksia tunteiden johtamisesta ja tunteista työpaikoilla.

Keskustelussa todettiin, että tunteet ovat työssä kaikilla mukana - paitsi työntekijöillä, myös erilaisilla sidosryhmillä, kuten asiakkailla. Tunteiden johtaminen ei olekaan pelkästään johtajien tehtävä, vaan koko työyhteisön on osallistuttava talkoisiin. Muuten tunteet voivat kuormittaa kohtuuttomasti yksittäisiä ihmisiä. Työyhteisöllä voi myös olla kiintiö sille, kuinka paljon ja mitä tunteita se kestää. Voisi sanoa, että tunteille on oltava tilaa työpaikan pelisääntöjen rajoissa.

Tunteista puhutaan ja niistä tiedetään entistä enemmän, mutta, kuten Rantanen totesi jo luennollaan, tiedostamisen suhde käytäntöön (knowingdoing-ongelma) näkyy teeman ympärillä. Tutkimisen ohella tunteita tulisi myös elää enemmän. Paneelissa kannustettiin kokeilemaan ja mokailemaan rohkeasti - mitään ei synny ilman luovuutta.

\section{TUNTEITA TEEMARYHMISSÄ}

Teemaryhmissä istuttiin posket innostuksesta punaisina ja ilma oli ideoista sakea. Teemaryhmiä oli tutkijatapaamisen historiassa ennätykselliset parikymmentä ja niissä pohdittiin muiden muassa työelämän tutkimusta, henkilöstövoimavarojen kehittämistä, johtamista, aikuisten oppimista ja aikuispedagogiikkaa, aikuiskoulutusta, koulutuspolitiikkaa, perhetutkimusta ja vapaata sivistystyötä.
Teemaryhmissä tutkittiin tohtoreita korkeakoulutuksessa, ikääntyneiden mediakasvatusta, kielen oppimista, epävarmuutta koulutuksessa, ammatillista toimijuutta, työssä oppimista, yrittäjyyttä, uusia oppimisen muotoja, yhteisöllisyyttä sekä oppimisen, luovuuden ja tunteiden johtamista. Teemaryhmissä aikuiskasvatuksen laajuus näyttäytyi aikuisten eri elämänkenttien tutkimuksena ja käytännön kehittämisenä.

Erityisesti kielen päällä kuplivat tunteet eri yhteyksissä: tunteet oppimisessa, työn tekemisessä, muiden kanssa toimimisessa ja muutoksen kohtaamisessa. Teemaryhmät osoittivat, että tutkimuksen lisäksi myös monitieteistä ja ajankohtaista käytäntöä aiheesta löytyy.

\section{TAPAHTUMAN ANTI JA SUUNTAVIIVAT TULEVAAN}

Aikuiskasvatustieteen tutkijatapaaminen on tärkeä tilaisuus rakentaa aikuiskasvatustieteen identiteettiä ja luoda omaa profiilia tieteiden kentällä. Unohtamatta muita ajankohtaisia ja tärkeitä tutkimusteemoja, joita esiteltiin kattavasti tutkijatapaamisen teemaryhmissä, tapahtuma nosti erityisesti tunteet aikuiskasvatuksen tutkimuskentälle ja jopa sen keskiöön.

Tunteet eivät ole toki uusi ilmestys aikuiskasvatuksessa tai muissakaan tieteissä. Onhan viime aikoina tuotu esille esimerkiksi organisaatiotutkimuksessa, että Nokian menestystarina olisi voinut jatkua, jos organisaatiossa olisi osattu tunnistaa ja johtaa jaettuja tunnetiloja. Aikuiskasvatustieteilijöinä meidän pitääkin pohtia ja tarkentaa, mitä uutta ja innovatiivista me voimme antaa tunteisiin liittyvään keskusteluun ja tutkimukseen.

Aikuiskasvatuksen tutkijatapaaminen osoitti tieteenalamme tarpeellisuuden. Tutkijatapaamisen osallistujat saivat kiitosta osaamisestaan ja palautetta siitä, että aikuiskasvatustieteellisellä tutkimuksella olisi paljon enemmän annettavaa esimerkiksi johtamisen kehittämiseen, kuin mitä siitä tällä hetkellä hyödynnetään. Otammeko haasteen vastaan, kaivaudummeko omista poteroistamme ja lähdemme tuomaan tietämystämme esille vahvemmin johtamisen kehittämisessä sekä yleensäkin toimimaan aktiivisemmin tieteen kentillä ja yhteiskunnallisessa keskustelussa?

On meistä itsestä kiinni, kuinka vahvistamme identiteettiämme tieteiden kentässä sekä pidämme 
tieteenalamme elinvoimaisena yhteiskunnallisissa ja akateemisen maailman myllerryksissä. Keväällä Yleisradio hakee Suomi-tekoja eli ehdotuksia ja ideoita, miten Suomesta tehdään paras mahdollinen paikka meille. Entäs Aikuiskasvatus-teot: millaisia tekoja sinä ja minä - me - voisimme tehdä aikuiskasvatustieteen kehittämiseksi ja näkyvämmäksi tekemisessä?

\section{LOPPUMETREILLÄ}

Valoa tulvivat lasiseinät, leppoisasti virtaavat tunteet, kohtaamisia, kimmeltävät kuohuviinilasit sekä ajatuksia pursuavat päät. Tunteita herättävä ja koskettava yhteinen hetki akrobaattisen tanssiesityksen äärellä. Tutkijatapaaminen saavutti sen, mitä tavoiteltiin: tiede ja työelämän kehittäminen löysivät sopivasti sopusointuja ja säröjä oppimisessa, luovuudessa ja tunteissa ja jäivät kosketusetäisyydelle

Merianna Rossi

tutkimusavustaja, aikuiskasvatustieteen opiskelija

Katja Vähäsantanen

$K T$, tutkijatohtori

Päivi Hökkä

$K T$, yliopistotutkija

Susanna Paloniemi

$K T$, yliopistonlehtori

Kasvatustieteiden laitos

Jyväskylän yliopisto toisistaan. Toivottavasti tapahtumassa syntyneet uudet ideat ja luodut kontaktit kantavat pitkälle tulevaisuuteen rikastuttaen aikuiskasvatuksen eri kenttiä sekä mahdollistavat työelämän ja koulutuksen kehittämisen innostavalla ja kestävällä tavalla.

Tutkijatapaamisen järjestelytoimikunta, johon kirjoittajien lisäksi kuuluivat Aikuiskasvatuksen tutkimusseurasta Jenni Pätäri, Katriina Tapanila ja Tiina Tuijula, kiittää lämpimästi luennoitsijoita, panelisteja, teemaryhmänvetäjiä, esitysten pitäjiä sekä kaikkia osallistujia onnistutuneesta ja innostavasta tilaisuudesta. Erityiskiitos menee Jyväskylän yliopiston kasvatustieteen ja aikuiskasvatuksen opiskelijoille, jotka olivat aktiivisesti, innostuneesti ja hymyssä suin mukana tapahtuman järjestämisessä. Vilpitön kiitos myös Ruusupuiston upeille vahtimestareille Sami Kokolle ja Timo Rossille, joilta löytyi kädenkäänteessä ja myös hymyssä suin ratkaisu ongelmaan kuin ongelmaan.

\section{TUTKIMUSPÄIVÄT 2018 JOENSUUSSA}

Aikuiskasvatuksen tutkijatapaaminen järjestettiin 18.-19. helmikuuta 2016 Jyväskylän yliopiston Ruusupuistossa. Tapahtuman teemana oli tänä vuonna teemalla Oppiminen, luovuus ja tunteet aikuisuuden eri elämänkentillä. Tapahtuma kokosi yhteen yli 200 eri alojen tutkijaa, opettajaa, johtajaa ja asiantuntijaa yliopistoista ja korkeakouluista, kansalais- ja aikuisopistoista, aikuiskoulutuskeskuksista, järjestöistä ja liitoista.

Aikuiskasvatuksen tutkijatapaaminen on joka toinen vuosi järjestettävä aikuiskasvatuksen suurin kotimainen tapahtuma. Tapahtuman järjesti tänä vuonna Jyväskylän yliopiston kasvatustieteiden tiedekunta ja Aikuiskasvatuksen tutkimusseura. Seuraavat Aikuiskasvatuksen tutkimuspäivät järjestetään Joensuussa vuonna 2018. 